\title{
Pragmatism and the Writing of History
}

\section{Roberto Gronda and Tullio Viola}

\section{(2) OpenEdition}

\section{Journals}

Electronic version

URL: http://journals.openedition.org/ejpap/623

DOI: 10.4000/ejpap.623

ISSN: 2036-4091

\section{Publisher}

Associazione Pragma

\section{Electronic reference}

Roberto Gronda and Tullio Viola, « Pragmatism and the Writing of History », European Journal of Pragmatism and American Philosophy [Online], VIII-2 | 2016, Online since 16 January 2017, connection on 10 December 2020. URL : http://journals.openedition.org/ejpap/623 ; DOI : https://doi.org/ 10.4000/ejpap.623

This text was automatically generated on 10 December 2020.

\section{cc)}

Author retains copyright and grants the European Journal of Pragmatism and American Philosophy right of first publication with the work simultaneously licensed under a Creative Commons AttributionNonCommercial-NoDerivatives 4.0 International License. 


\title{
Pragmatism and the Writing of History
}

\author{
Roberto Gronda and Tullio Viola
}

1 The contributions presented in this symposium explore, from different perspectives, the relationship between pragmatism and history, that is, the empirical study of the human past. These connections run deep, and may be assessed on several counts.

2 First of all, many pragmatist philosophers have devoted a great deal of attention to investigating the nature of historical knowledge and its relevance to philosophy. Classical pragmatists such as Peirce, Dewey and Mead laid a strong emphasis on processuality and evolution as fundamental philosophical categories. At the same time, they rejected intuitionist or a-priorist conceptions of knowledge, advocating instead a continuity between philosophy and empirical inquiry. This approach was also sustained by their general skepticism towards overly closed systems, and by a keen interest in individuality and the unexpected consequences of experience. In this sense, it is not an accident of their intellectual biographies that they also painstakingly reflected on the methodology of historiography, and dedicated themselves in first person to concrete historical studies (in particular, of science). ${ }^{1}$

3 In continuance of the original insights of the classical pragmatists, so-called neopragmatism is significantly concerned with the issue of historicity. Morton White, Richard Rorty, Hans Joas, Joseph Margolis - to name some of the most prominent figures - have all contributed to the ongoing discussion over history's relevance to philosophy, although in ways that are certainly not subsumable under a single perspective. At the same time, some major representatives of recent discussions in the philosophy of history have recognized pragmatism as a crucial interlocutor, in particular with regard to the philosophical puzzles that concern the nature of our knowledge about the past. ${ }^{2}$

4 The interest of pragmatist philosophers in history is accompanied by a complementary interest of professional historians in pragmatism. Such interest dates back to the first decades of the twentieth century, with the work of influential historians (almost all based at Columbia University, where pragmatism was exerting a strong intellectual 
influence) such as James Harvey Robinson, Charles and Mary Beard, Merle Curti, John Herman Randall Jr., Carl Becker and Richard Hofstadter. ${ }^{3}$ But it still endures today, both in America and Europe, in new and original forms. Some recent historians have even greeted the advent of a new "pragmatist" or "pragmatic" turn in their discipline: an attitude that combines some original pragmatist tenets with insights coming from different traditions. ${ }^{4}$ By so doing, they have also contributed to a larger debate that is taking place among social scientists about the spatial and temporal situatedness of human action. And, indeed, the role of the social sciences must not be underestimated. Starting with Dewey and Mead, the reflection on pragmatism and history has gone hand in hand with a broader reflection on the status of the social sciences.

5 In the attempt to take seriously this diversity of approaches, the present symposium is directed both to philosophers who approach history with a distinctively philosophical agenda in mind, and to historians or historically-minded social scientists who have seen in pragmatism an important source of clarification, conceptual or methodological alike.

6 The essays, interview and reviews that make up the symposium aspire to depict different aspects of our central question. A first block of papers offers interpretive approaches to the thought of classical pragmatists. Ambrosio, Colapietro, and Topa focus on Peirce's interest in both the philosophy of history and history as an empirical discipline; Niklas looks at the debate on historical knowledge that has involved many pragmatists of the early twentieth century; Huebner analyzes Mead's work as a historian and philosopher of history. A second block of papers considers some crucial insights of classical pragmatism in relation to more encompassing debates about the relevance and purport of historical knowledge. Andrew Abbott investigates Dewey's and Mead's understanding of temporality in the context of a processual approach to social theory; Laas' and Tozzi's essays reflect on the relevance of Peirce, Dewey and Mead to actual discussions about narrativism and realism; and Jonathan Gorman looks back at his own intellectual path as a philosopher of history influenced by pragmatist ideas. Finally, David Marshall explores the work of Max H. Fisch, a twentieth-century intellectual historian who found a major source of inspiration in his monumental study of Peirce.

7 The essays are followed by some further material. Oliver O'Donnell publishes here for the first time (and supplies with an introductory essay) a manuscript by Allan Marquand, the Princeton art historian and ancient student of Peirce's who, in the text here presented, is shown to seize on Peircean philosophy to articulate the tasks of art history. Finally, two interviews complete the symposium: the first is with Hans Joas, who has repeatedly written about pragmatism's ability to reconcile genetic and systematic (or normative) approaches to the study of concepts and values; and the second is with Paris historians Yves Cohen and Simona Cerutti, two major proponents of a "pragmatist" approach to history (see also Bruno Settis's review).

8 As is easy to see from this brief survey, we have explicitly eschewed a systematic approach to the topic of pragmatism and history - an approach that would have forced the exchanges we aim to reconstruct into the procustean bed of pre-established categories. Nor have we tried to suggest that pragmatism enjoys some sort of "special relationship" to history. We are well aware that, on the one hand, there have been pragmatist philosophers who were not especially interested in history; and on the other, there have been other philosophical traditions (such as phenomenology or 
Marxian thought) which had an even stronger impact on historiographical practice than pragmatism.

9 We do believe, however, that pragmatism has been, is and will likely continue to be an important interlocutor for historians and philosophers of history, in virtue of some profound theoretical motives that are inscribed into its very roots. From a variety of angles, all texts presented here shed light on this basic conviction. Our task will be achieved if we contribute to furthering the exchange between pragmatism and historical studies, by inviting scholars to address the purport of a dialogue that, more or less implicitly, has been going on for decades.

\section{BIBLIOGRAPHY}

ANKERSMIT F., (2005), Sublime Historical Experience, Stanford, Stanford University Press.

DEWEY J., (1986 [1938]), Logic: The Theory of Inquiry, in John Dewey. The Later Works, 1925-1953, vol. 12, ed. by J. A. Boydston, Carbondale, Southern Illinois University Press.

GALLIE W. B., (1952), Peirce and Pragmatism, Harmondsworth/Middlesex, Penguin.

GALLIE W. B., (1964), Philosophy and the Historical Understanding, London, Chatto \& Windus.

KLOPPenBerg J. T., (2004), "Pragmatism and the Practice of History. From Turner and Du Bois to Today," Metaphilosophy, XXXV/1-2 (Jan.), 202-25.

MEAD G. H., (1932), The Philosophy of the Present, ed. by A. E. Murphy, Chicago, Open Court.

MEAD G. H., (1936), Movements of Thought in the Nineteenth Century, ed. by M. H. Moore, Chicago, University of Chicago Press.

PEIRCE C. S., (1985), Historical Perspectives on Peirce's Logic of Science. A History of Science, ed. by C. Eisele, 2 vols, Berlin/New York/Amsterdam, Mouton Publishers.

\section{NOTES}

1. See in particular Peirce 1985; Mead 1932, 1936; Dewey (1938: Ch. 12).

2. See Ankersmit 2005. For an earlier reception, see Gallie 1952 and 1964.

3. See Kloppenberg 2004, whose title is intentionally echoed by that of the present symposium.

4. See the conversation with Yves Cohen and Simona Cerutti in the symposium. 


\section{AUTHORS}

\section{ROBERTO GRONDA}

Università di Pisa

roberto1gronda[at]gmail.com

\section{TULLIO VIOLA}

Humboldt Universität zu Berlin

tullio.viola[at]gmail.com 